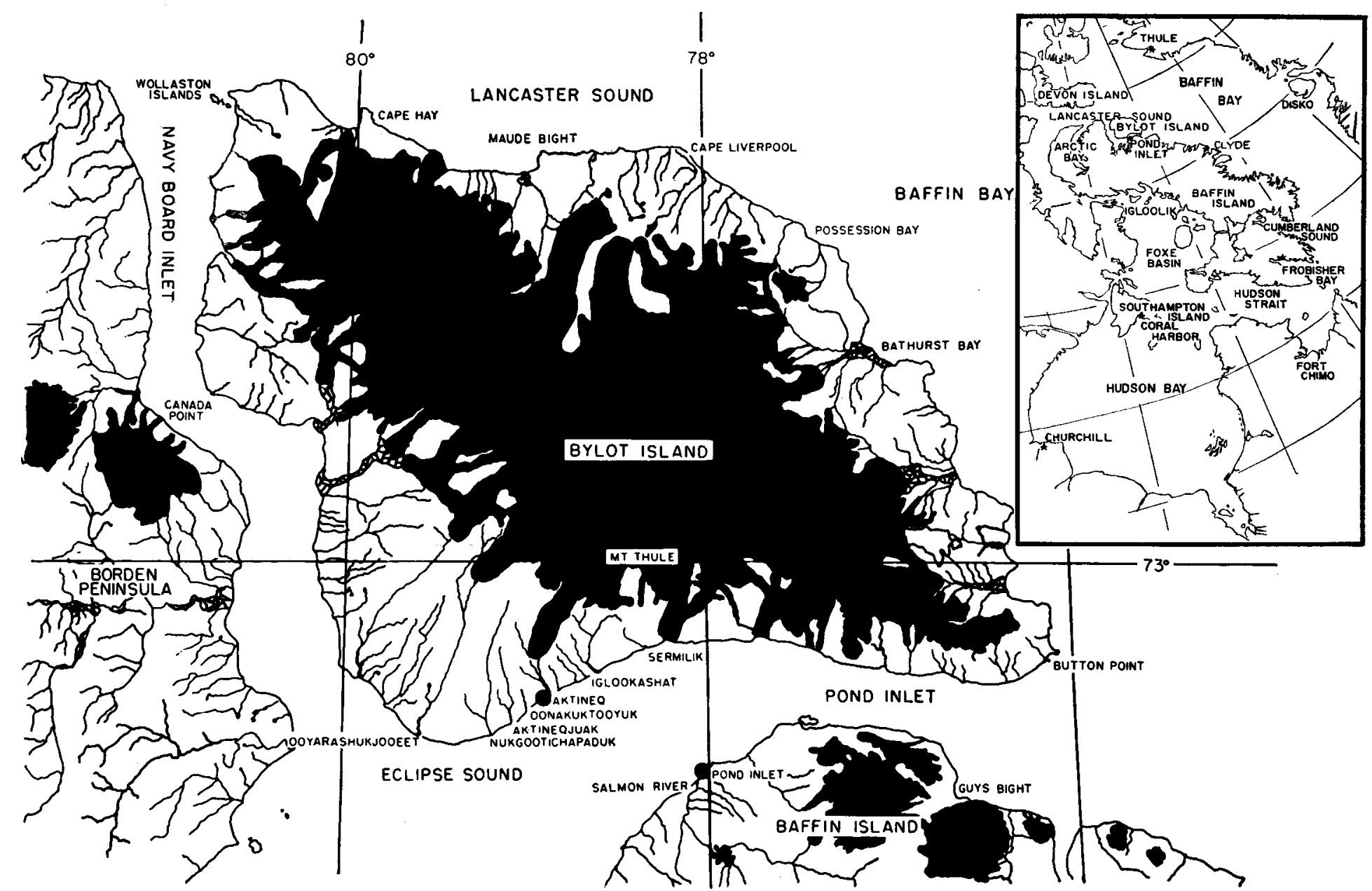

Fig. 1. Bylot Island, scale $1^{\circ}$ longitude approximately 20 miles. Glaciers and snowfields shaded black. Black dots mark the expedition's camp site at the mouth of the Aktineq River, and the Hudson's Bay Company trading post at Pond Inlet, Baffin Island. 


\title{
A SURVEY OF THE MAMMALS OF BYLOT ISLAND, NORTHWEST TERRITORIES
}

\author{
Richard S. Miller*
}

$\mathbf{T}$ The 1954 Bylot Island expedition was organized under the auspices of the Arctic Institute of North America, with additional support from the New York Zoological Society, to survey the flora and fauna of Bylot Island, and to study certain ecological problems. A general description of the activities of the expedition has been prepared (Drury, 1954) but the present paper reports only on the mammals of Bylot Island and its surrounding waters. It is based mainly on observations made in the field by the writer and other members of the expedition; data were also obtained from Arctic Wildlife Enquiry reports prepared by the Pond Inlet Detachment of the Royal Canadian Mounted Police, and the fur returns of the Hudson's Bay Company were made available to us. Discussion with the Tununermiut Eskimo proved most valuable, as they are accurate and reliable observers and could provide information on all seasons. Experience showed that certain Eskimo were better informed than others about particular animal species, and every attempt was made to take advantage of this.

Most of the Eskimo live on the shores of Pond Inlet, Eclipse Sound, Tay Sound, and Navy Board Inlet. There is one permanent camp at Iglookashat on Bylot Island, and a summer camp at Button Point. Hunting and trapping is confined mainly to Baffin Island and the south coast of Bylot Island, but occasionally the Eskimo travel as far north as Lancaster Sound and the Wollaston Islands, and to Maud Bight on the northeast coast of Bylot Island. They trade at Pond Inlet and make it their summer headquarters, so they were available for frequent questioning.

Idlouk, the most energetic and skilled hunter of the Tununermiut group, was attached to the expedition during our stay. His written notes on the annual abundance, migrations, and general habits of various animal species were extremely valuable.

Bylot Island is about 4,000 square miles in area, and is separated from Baffin Island by the waters of Pond Inlet, Eclipse Sound, and Navy Board Inlet (Fig. 1). The surface of the island consists mainly of rocky peaks projecting through highland ice (Fig. 2), and the only extensive lowlands are on the southwest and northeast coasts. A central mountain range forms a broad ridge along the axis of the island, stretching from Wollaston Islands in the northwest to Button Point in the southeast.

*Experiment Station, Colorado Agricultural and Mechanical College. 


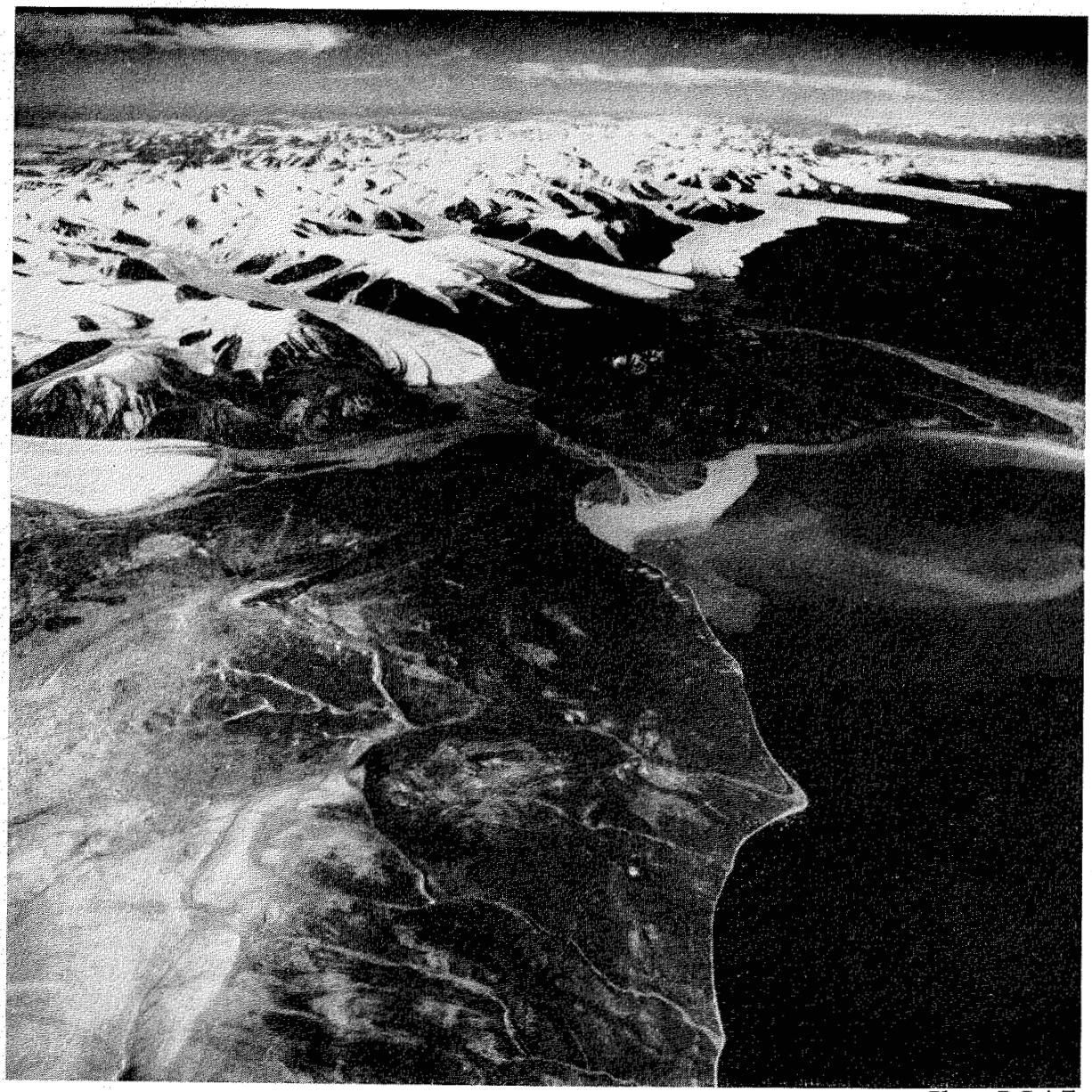

Fig. 2. View east from Canada Point.

The expedition camp was established on lowland on the south shore of the island, just west of the mouth of the Atkineq River, on 14 June 1954, and maintained until July 31. Observations were made at points along the south coast from Button Point to Ooyarashukjooet. During the frequent crossings between the Bylot Island camp and Pond Inlet, a distance of about twenty miles, and on other dog sled trips on the sea ice of Pond Inlet and Eclipse Sound, observations on aquatic mammals were possible.

The vegetation of the south coast, the only area visited by the expedition, varies with the topography, exposure to sun and wind, and frost action. The dominant vegetation is Salix arctica, Dryas integrifolia, and Luzula confusa. Luzula confusa is particularly abundant on exposed, well-drained soils, where it forms a complex with Saxifraga oppositifolia, Papaver radicatum, and the lichens Stereocaulon and Cetraria. Sheltered areas with more moisture have 
heavier growths of mosses and Cassiope tetragona, while the exposed, windblown areas and extremely well-drained soils are characterized by lichens, Papaver saxifraga, and Salix. Salix berbacea is characteristic of places sheltered from wind and sun, where snow tends to accumulate and remain for a long time.

Lemming mounds are the centres of a distinct vegetation complex. Progressive burrowing into solifluction lobes, frost cracks, and at the bases of boulders, and the accumulation of fecal material seems to contribute to a lush, grassy vegetation.

\section{Mammal species}

The Tununermiut names for the animals have been listed for the convenience of others who might study in this area. These names were provided by the Pond Inlet Eskimo, through Peter Murdoch, of the Hudson's Bay Company, who interpreted their references and spelling.

Species determinations were, in most cases, made directly from field observations with reference to Burt and Grossenheider (1952). Species not actually observed by members of the expedition were identified by the Eskimo from the illustrations in Burt and Grossenheider. Repeated tests showed that such identifications were extremely accurate and that even subtle specific differences were noted. The specific names used are those listed by Miller and Kellogg (1955).

Thalarctos maritimus. Polar Bear. Nanook.

Polar Bear are known from the Wollaston Islands east along the north coast of Bylot Island and along the east coasts of Bylot and Baffin islands. The relative abundance of this species is difficult to determine, since bears are seldom hunted anywhere but at the floe edge of Pond Inlet. The total annual kill by the Pond Inlet Eskimo is estimated at about 20 to 25, but as the hides are rarely traded there is no reliable index of numbers. Idlouk says that more bears could be taken if the hunters were to go farther afield and search for them.

\section{Mustela erminea. Short-Tailed Weasel. Tereak.}

According to the Eskimo, weasels are common along the southern coast and on the lowlands between Canada Point and Iglookashat. Several were seen by members of the expedition, usually near river beds, but once at an altitude of 3,500 feet at the edge of Sermilik Glacier.

\section{Alopex lagopus. Arctic Fox. Terereneak.}

This species is found throughout the lowlands of Bylot Island and is particularly abundant along the southern coast.

Table 1 shows the number of fox trapped annually by the Pond Inlet Eskimo for the past thirty-two years. These data are from the Hudson's 
Bay company fur returns, in which a season is the period from July 1 to June 30 of the next year. The estimates of lemming abundance are from Arctic Wildlife Enquiry reports. The records for both fox and lemming are illustrated graphically in Fig. 3.

Table 1. Seasonal abundance of arctic fox and lemming in the Pond Inlet area.

Season

1921-22

$1922-23$

1923-24

$1924-25$

$1925-26$

$1925-26$

1926-27

$1927-28$

1928-29

$1930-31$

1931-32

1932-33

$1933-34$

$1934-34$

1935-36

1936-37

1937-38

1938-39

1939-40

1940-41

1942-43

$1942-43$
$1943-44$

1944-45

1945-46

1946-47

$1947-48$

$1949-50$

1949-50

1950-51

1952-53

1953-54

Arctic Fox
$\mathbf{3 1 8}$
1048
1355
312
1105
1866
844
382
1333
3515
2384
479
2811
3113
904
450
1698
971
700
844
933
1020
342
988
1309
839
503
$\mathbf{5 7 0}$
$\mathbf{5 3 1}$
857
1347
350
536

Lemming

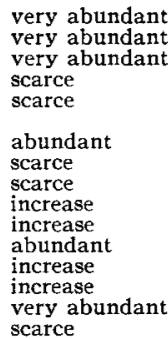

very abundan

very abundant

scarce

abundant

scarce

increas

increase

scarce

1. Published by permission of the Fur Trade Department, Hudson's Bay Company.

The periodicity of the maxima and minima in the data for fox numbers is shown in Table 2. The value of 318 for 1921-22 (Table 1) cannot be compared with data from the previous year, and has not been included. Authors disagree as to how peaks should be chosen, but the figure of 570 for the 1948-49 season (Table 1) has not been treated as a peak, on the grounds argued by Butler (1953). Thus the values shown in Table 2 give a mean periodicity of 4.0 years for the maxima and minima, conforming to the usual periodicity assigned to this species in this part of its range (Chitty, 1950,

Table 2. Periodicity in the maxima and minima of fur returns for arctic fox in the Pond Inlet area from 1921-22 to 1953-54.

Maxima
$1923-24$
$1926-27$
$1930-31$
$1931-35$
$1937-38$
$1942-43$
$1945-46$
$1950-51$
Total
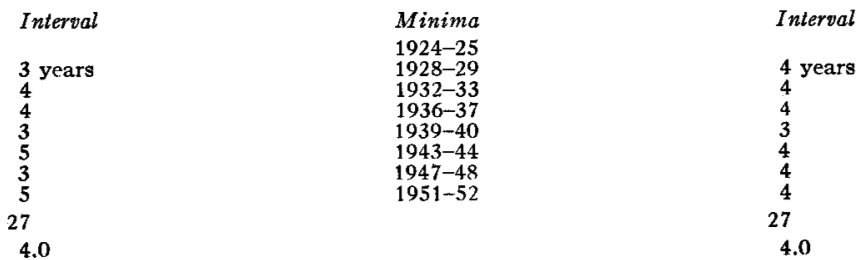


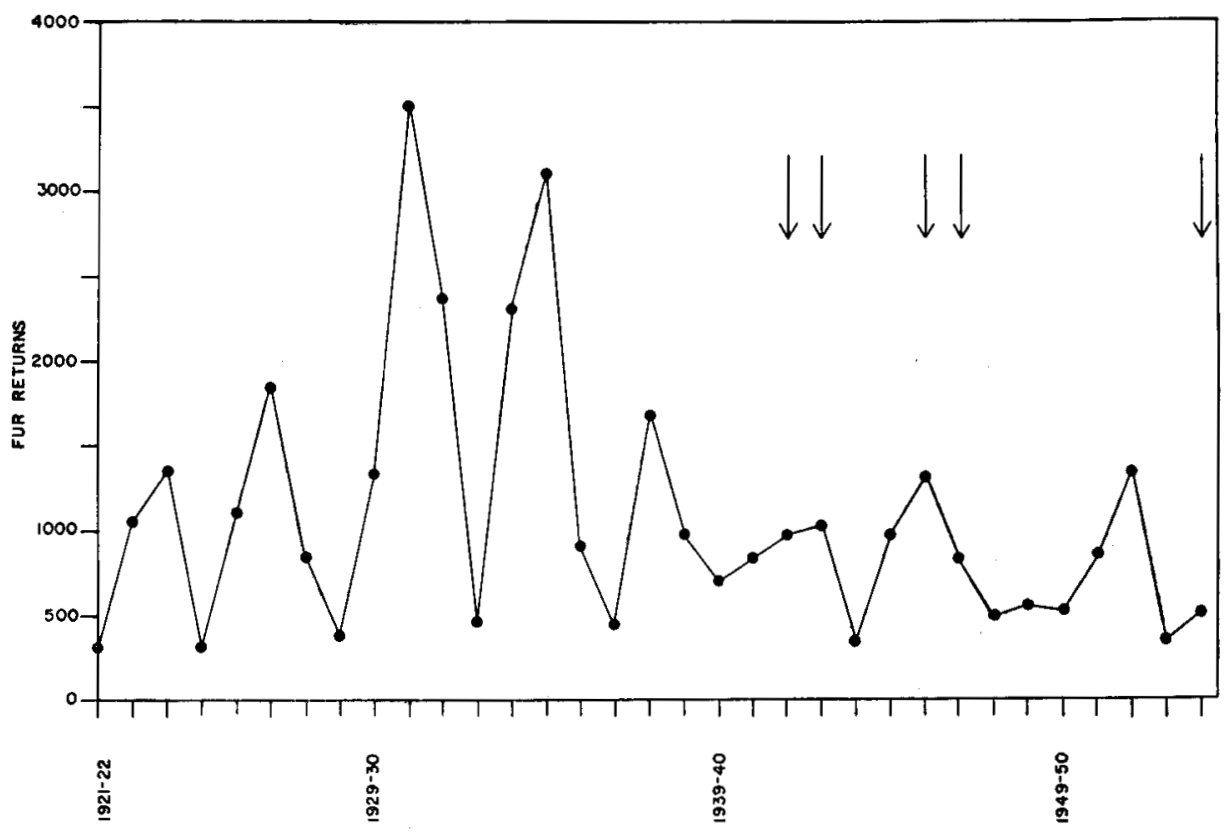

Fig. 3. Hudson's Bay Company fur returns for arctic fox at Pond Inlet from 1921-22 to 1953-54. Seasons of lemming scarcity are indicated by arrows.

pp. 182-3; Butler, 1953, pp. 246-7). It should be noted that the periods of relative abundance and scarcity of each of the "cyclical species" on Bylot Island correspond with those on Baffin Island.

Canis lupus. Gray Wolf. Amarak.

Wolves have not been seen on Bylot Island since the elimination of the caribou herd in 1943.

Phoco hispida. Ringed Seal. Netcbek.

This is the common seal in the waters around Bylot Island and throughout this part of the eastern Arctic, and it is the principal animal in the economy of Eskimo. There is no reliable way of estimating its numbers or how many the Eskimo kill. Idlouk, who keeps an account of his game kill, says that his yearly kill is between 200 and 300 ; Idlouk is an exceptional hunter, but he also supplements his diet with other animals. If Idlouk's average were extended to the other hunters, it would mean an annual total kill of about 11,250 seals.

The stomachs of 8 seals taken in Eclipse Sound and Pond Inlet contained a large species of gammarid, which the Eskimo claim is the principal prey of the ringed seal, young and adults alike. During the spring and summer the seals do not seem to eat many fish, even though arctic char (Salvelinus alpinus) are abundant. On several occasions seals were seen among the ice floes offshore from the Salmon River near Pond Inlet, where char gathered during 
their migration, but the seals did not move inshore to feed on the fish nor did the stomachs of seals taken in this area contain fish.

Phoca groenlandica. Harp Seal. Kyrolik.

The harp or saddleback seal is found in Pond Inlet and Navy Board Inlet at the end of July or early in August, during an annual migration into Tay Sound, south of Eclipse Sound. These seals are quite numerous at Guys Bight

Table 3. Arrival date of bearded seal and narwhal in Eclipse Sound, compared with date of ice break-up, yearly since 1946.

\begin{tabular}{|c|c|c|}
\hline Year & $\begin{array}{l}\text { Arrival of narwhal } \\
\text { and bearded seal }\end{array}$ & $\begin{array}{c}\text { Date of } \\
\text { Ice break-up }\end{array}$ \\
\hline $\begin{array}{l}1946 \\
1947 \\
1948 \\
1949 \\
1990 \\
1951 \\
1952 \\
1953 \\
1954\end{array}$ & $\begin{array}{l}30 \text { July } \\
26 \text { July } \\
1 \text { August } \\
26 \text { July } \\
25 \text { July } \\
21 \text { July } \\
25 \text { July } \\
23 \text { July } \\
18 \text { July }\end{array}$ & $\begin{array}{l}11 \text { August } \\
7 \text { August } \\
28 \text { July } \\
27 \text { July } \\
23 \text { July } \\
17 \text { July } \\
4 \text { August } \\
4 \text { August } \\
7 \text { August }\end{array}$ \\
\hline
\end{tabular}

and in the northernmost waters of Navy Board Inlet, both close to their normal migration route in Baffin Bay; fairly large numbers enter Eclipse Sound from Navy Board Inlet and Pond Inlet and pass into Tay Sound along the same migration path followed by narwhal. They stay in Tay Sound until about September 25 and move out again into the open sea as ice begins to form.

Erignathus barbatus. Bearded Seal. Oogjuk.

The Eskimo report that bearded seals sometimes winter in Eclipse Sound and Pond Inlet, but they are usually seen only in summer. Since these animals are rather solitary and prefer open water, they are never very abundant in this area.

Bearded seals invariably enter the inland waters on the same day as narwhal. Table 3 shows the annual arrival of bearded seal and narwhal compared with the dates of ice break-up in these waters. These records are from the annual log kept by Idlouk, who defines the ice break-up as the first day a boat can safely cross Eclipse Sound. When the expedition left Bylot Island on July 31, Idlouk correctly estimated that it would be another week before the ice on Eclipse Sound would be open.

The two species are seen as much as twelve days before the ice breaks up, but show only eleven days range in their dates of arrival over the period for which data are available, as compared with a range of twenty-five days in the dates of ice break-up. Since the ice sometimes remains in the sounds until the second week of August and begins to reform about the middle of September, the migratory movements of mammals that prefer open water are restricted to a short period in this area. The bearded seal and narwhal are, however, able to use limited spaces of open water and can move into the sounds and inlets before they are free of ice. 
Cystophora cristata. Hooded Seal. Apa.

A few hooded seals occasionally enter Pond Inlet and Eclipse Sound in the summer with harp seals; no more than 3 have ever been seen in a year. The Eskimo are, however, familiar with the hooded seal and recognize it readily by its habit of swimming low in the water with only the top of the head exposed and by the inflatable sac on the nose of the males.

Odobenus rosmarus. Walrus. Ivik.

One of the northernmost breeding grounds of the walrus is the Wollaston Islands, off the northwest tip of Bylot Island, but walrus are reportedly abundant all through Lancaster Sound. The Pond Inlet Eskimo generally hunt them along the floe edge of Pond Inlet and the total kill is only about 10 each year. A few of the Eskimo have made boat trips to the Wollaston Islands to hunt; their reports of the population size vary considerably and are probably not reliable. The most conservative estimate places the breeding population between 200 and 300 adults.

Lemus trimucronatus. Brown Lemming. Avignak, Kayook.

No brown lemmings were found by the expedition, either on Bylot Island or Baffin Island, although both are within its range of distribution (Miller and Kellogg, 1955, p. 566). The Eskimo say that the brown lemming is found on the island, but is not as common as the Greenland collared lemming. They readily identified both the brown and Greenland collared lemmings from illustrations, and though the word avignak is used for any lemming, they have different names for the two species.

Dicrostonyx groenlandicus. Greenland Collared Lemming. Avignak, Amiglak.

The summer of 1954 was a period of lemming scarcity, following a peak in 1953, and only 4 Dicrostony $x$ were taken; one of these was from a strictly natural habitat on Bylot Island, the other 3 were living under the buildings of the Hudson's Bay Company at Pond Inlet.

This species reportedly reaches high densities in the southwest lowlands, where favourable habitat is most extensive. A particularly intensive search for lemmings and snowy owls was made in the vicinity of Ooyarashukjooeet, where they had been most abundant in 1953. Except for sand or gravel areas where vegetation was sparse, it was impossible to walk across the tundra slopes without stepping on lemming runs or burrows, yet trapping was fruitless and all evidence of lemming activity proved to be from previous years. Only one snowy owl was seen and very few of a large sample of owl pellets were fresh.

The vegetation in this area was examined closely for evidence of heavy browsing or damage to food plants by lemmings. The stems of some of the older willows had been barked, but not extensively, and there was nothing to indicate that food or habitat conditions were unfavourable. If, as some authors 
maintain (Lack, 1954, pp. 214-6, 223, 226), food is a primary factor in lemming "crashes", the effect on the flora should be apparent in the years following peak numbers. The Eskimo report that Salix arctica is the principal food plant of the lemmings, although they will also eat most of the other herbs and grasses; captive lemmings ate the young leaves of all willow species and the stems and leaves of Carex misandra and seemed to stay healthy. These plants were abundant everywhere in the tundra.

None of the Eskimo had seen a lemming migration, and such a thing is not recorded in their folk tales. They have seen lemmings on ice floes at the water's edge during periods of high numbers, but never more than a few at a time.

\section{Lepus arcticus. Arctic Hare. Okalek.}

A few arctic hares are found on the lowlands of Bylot Island. They are never as abundant on Bylot Island as they are near Pond Inlet, but periodic fluctuations in numbers are apparently synchronous in the two populations. This was learned from the Arctic Wildlife Enquiry reports and from statements by the natives.

\section{Rangifer arcticus. Barren Ground Caribou. Tuktoo.}

For some years caribou were known to be on the northeast coast of Bylot Island. The only route to this area is along the east coast where the ice is often impassable during winter, and the caribou were, therefore, beyond the reach of native hunters. In 1941, however, for the first time in several years, a party of Eskimo was able to negotiate the ice along the coast and found a fairly large herd on the lowlands near Cape Liverpool. They killed 149 deer. In 1942 another caribou hunt was organized; the herd was found between Bathurst and Possession bays and 24 caribou were shot. In 1943 a hunting party journeyed to the north coast and killed 300 caribou in the area between Maud Bight and Cape Liverpool. Few if any survived this last onslaught, and subsequent attempts to find caribou on the island have been unsuccessful.

The Tununermiut are coastal people and rarely venture more than a few miles inland, so that if the caribou could move to an inland area they would probably not be molested. Bylot Island does not afford such a refuge, and since there are very few areas that can support caribou, it is therefore improbable that this species will ever survive on Bylot Island unless completely protected.

Balaena mysticetus. Bowhead Whale. Akbilk.

Following Parry's voyage to Possession Bay in 1819, the waters off the east coast of Bylot Island became one of the most famous of the northern whaling grounds and the floe edge at Button Point was visited frequently by whalers during the next half century. Now, seldom more than a few whales are seen each year off Button Point and only occasionally do they enter Pond Inlet and Navy Board Inlet. 
Whale skeletons are fairly numerous along the beaches of Pond Inlet, Eclipse Sound and Navy Board Inlet, and are sometimes found on raised beaches as much as two miles inland and 200 feet above the present shore. The Eskimo have no stories to account for these skeletons. The identification of this species was made by $W$. Schevill (personal communication) from photographs of skulls found along the beaches.

Grampus orca. Atlantic Killer Whale. Ahgluk.

At least 10 to 20 killer whales are seen in Eclipse Sound and Pond Inlet every August, apparently following the migratory mammals already discussed and preying on the ringed seals. The whales, in packs, drive the seals inshore where they are easy game for the Eskimo.

Delphinapterus leucas. White Whale. Kaudlookta.

This species is fairly common in Lancaster Sound where about 100 to 200 are seen in June and July each year at the floe edge of Pond Inlet. Sometimes 10 or 15 are seen in the inland waters of Eclipse Sound, usually in August, but this is not a regular occurrence.

\section{Monodon monoceros. Narwhal. Kilaluga.}

During late July narwhal enter Navy Board Inlet from Lancaster Sound, and Pond Inlet from Baffin Bay; they generally follow two migration paths that converge in Eclipse Sound off the southwest tip of Bylot Island. Between 500 and 1,000 are seen along the southern coast of the island every year, travelling in groups of as many as 200. From Eclipse Sound they move south into Tay Sound where they stay until ice begins to form in September. As mentioned earlier, the arrival of this species invariably coincides with that of the bearded seal.

The first narwhal seen on this expedition were in an area of open water at the mouth of the Aktineq River on the morning of July 18. Their progress could be followed from some distance, by the sound of their blowing when they surfaced. Several were located in this manner and observed from the ice at close range as they passed along the leads. Of the 22 narwhal seen between July 18 and 30 , only 4 had tusks sufficiently prominent to identify them as niales.

The Eskimo had reported that narwhal often surface in seal holes, which are enlarged late in the season by the runoff of melt water from the surface of the ice. Since the largest of these holes is seldom more than fifteen or twenty feet in diameter, this seemed somewhat improbable; however, 4 females were watched for about ten minutes as they surfaced, one or two at a time, in a single seal hole which was not more than eighteen or twenty feet across. They seemed to maintain a steady rhythm of rising, heads pointed upwards, then sliding back beneath the surface, and continued to surface in this fashion until we had crept to within about twenty feet of them.

Whales with two tusks are sometimes seen. Idlouk has a photograph of a narwhal killed in Tay Sound in 1953, with one tusk four feet long and 
the other three feet long. The Pond Inlet Eskimo think that the narwhal tusks are used in fighting, but can give no real evidence to support this hypothesis.

I wish to thank the Hudson's Bay Company for permission to publish the fur returns shown in Table 1. I am also grateful to Peter Murdoch of the Hudson's Bay Company and Constable Moody, of the Royal Canadian Mounted Police, for help and advice during this study, and especially to Eskimo Idlouk, whose companionship and contributions were invaluable.

\section{References}

Burt, W. H. and R. P. Grossenheider. 1952. 'A field guide to the mammals'. Boston: xii +200 pp.

Butler, L. 1953. "The nature of cycles in populations of Canadian mammals". Can. J. Zool. Vol. 313, pp. 242-62.

Chitty, Helen. 1950. "Canadian Arctic wildlife enquiry, 1943-49: with a summary of results since 1933". J. Anim. Ecol. Vol. 19, pp. 180-93.

Drury, W. H. 1954. "The 1954 Bylot Island Expedition". Unpublished MS.

Lack, D. 1954. 'The natural regulation of animal numbers'. Oxford: viii $+343 \mathrm{pp}$.

Miller, G. S., Jr. and R. Kellogg. 1955. 'List of North American recent mammals'. U.S. Nat. Mus. Bull. No. 205, xii +954 pp. 